\title{
Perancangan Media Pembelajaran Berbentuk Pop Up Book untuk Pencapaian Kemampuan Memecahkan Masalah Matematis pada Materi Aritmatika Sosial
}

\author{
Fitri Andayani1,", Sri Adi Widodo², Denik Agustito ${ }^{3}$ \\ 1,2,3 Universitas Sarjanawiyata Tamansisa \\ *Fitriandayani24@gmail.com
}

\begin{tabular}{|l|l|l|l|}
\hline Received : 25-10-2021 & Revised: $18-11-2021$ & Accepted: 22-11-2021 & Published: 21-12-2021 \\
\hline
\end{tabular}

\begin{abstract}
ABSTRAK
Penelitian ini bertujuan untuk mengetahui proses pengembangan media pembelajaran pop-up book untuk pencapaian memecahkan masalah matematis pada materi aritmatika sosial. Jenis penelitian yang digunakan adalah Research and development (R\&D). Penelitian ini merupakan penelitian pengembangan yang menggunakan model pengembangan 4D (four-D) yang meliputi empat tahapan yaitu pendefinisian (define), perancangan (design), pengembangan (develop) dan penyebaran (disseminate). Instrumen yang digunakan dalam penelitian ini menggunakan lembar validasi. Lembar validasi digunakan untuk mengetahui kevalidan dari media pop-up book pada materi aritmatika sosial. Hasil validasi yang telah diperoleh dari 7 validator kemudian dianalisis menggunakan persentase setiap item validasi. Kriteria produk dikatakan valid jika diperoleh persentase setiap item validasi produk minimal 70\%. Berdasarkan hasil analisis diperoleh skor ratarata kevalidan dari hasil validasi ahli media sebesar $80,57 \%$, ahli materi sebesar $84,286 \%$, dan ahli bahasa sebesar $83,88 \%$ dari hasil tersebut didapatkan kriteria valid dapat digunakan dengan revisi kecil. Disimpulkan bahwa media pembelajaran pop up book pada materi aritmatika sosial layak digunakan untuk meningkatkan pencapaian kemampuan pemecahan masalah matematis.
\end{abstract}

Kata Kunci: media pembelajaran, pop up book, pemecahan masalah matematis

\begin{abstract}
This study aims to determine the process of developing pop-up book learning media for the achievement of solving mathematical problems in social arithmetic material. The type of research used is Research and development $(R \& D)$. This research is a development research that uses a $4 D$ (four-D) development model which includes four stages, define, design, develope and disseminate. The instrument used in this study used a validation sheet. The validation sheet is used to determine the validity of the pop-up book media on social arithmetic material. The validation results that have been obtained from 7 validators are then analyzed using the percentage of each validation item. The product criteria are said to be valid if the percentage of each product validation item is at least $70 \%$. Based on the results of the analysis, the average validity score from the validation results of media experts is $80.57 \%$, material experts is $84.286 \%$, and linguists are $83.88 \%$. From these results, valid criteria can be used with minor revisions. It was concluded that the pop up book learning media on social arithmetic material was appropriate to be used to improve the achievement of mathematical problem solving abilities.
\end{abstract}

Keyword: learning media, pop up book, problem solving 


\section{PENDAHULUAN}

Pendidikan dalam pandangan yang luas adalah proses pembentukan pribadi dalam semua aspeknya, yaitu pembentukan aspek jasmani, akal, dan hati (Soeprapto, 2013). Undang-undang Sistem Pendidikan Nasional Nomor 20 tahun 2003 pasal 1 ayat 1 menyatakan pendidikan ialah usaha sadar serta terencana untuk menghidupkan suasana belajar dan pembelajaran untuk siswa agar aktif mengembangkan potensi dirinya yang meliputi kekuatan spiritual keagamaan, kecerdasan, kepribadian, akhlak mulia serta keterampilan yang diperlukan dirinya dan masyarakat, bangsa dan Negara. Maka dari itu dapat disimpulkan bahwa pendidikan memiliki andil besar dalam pembangunan suatu bangsa sama seperti pendapat Suryana (2017) yang menyatakan pendidikan harus lebih berperan dalam membangun seluruh potensi manusia agar menjadi subjek yang berkembang secara optimal dan bermanfaat bagi masyarakat maupun pembangunan nasional.

Pembelajaran matematika selalu berhubungan dengan pemecahan masalah. Pemecahan masalah dalam matematika merupakan kemampuan yang sangat penting dalam pembelajaran matematika (Septian, 2017). Hal ini menuntut siswa agar memiliki kemampuan dalam memecahkan masalah siswa diharapkan mampu mengidentifikasi, merancang dan menyelesaikan masalah matematika (Norhayati dkk, 2018). Banyak faktor yang membuat siswa cenderung tidak tertarik mempelajarinya diantaranya kurangnya pemahaman tentang materi yang akan dipelajari siswa sehingga matematika dianggap sulit bagi siswa (Fuadah dkk, 2013). Dalam pendidikan matematika, pemecahan masalah juga menjadi hal yang penting untuk ditanamkan pada diri siswa. Dengan pemecahan masalah matematika, siswa tidak akan kehilangan makna dalam mempelajari matematika karena suatu konsep atau prinsip akan bermakna jika konsep tersebut dapat diaplikasikan dalam pemecahan masalah (Widodo, 2013). Maka dari itu dibutuhkan sebuah inovasi baru dalam pembelajaran untuk mengatasi masalah tersebut, salah satu strategi yang dapat memecahkan masalah yaitu perancangan sebuah media pembelajaran yang dapat membantu siswa.

Pemecahan masalah mempunyai tujuan mendorong siswa lebih aktif untuk melakukan eksplorasi dalam menyelesaikan masalah (Bernard dkk, 2018). Namun, kenyataannya kemampuan pemecahan masalah matematika siswa Indonesia masih rendah, rendahnya kemampuan pemecahan masalah matematis siswa Indonesia ditinjau dari survei Program for International Students Assesment (PISA) tahun 2016 yang menunjukkan bahwa Indonesia menempati peringkat ke-64 dari 72 negara yang di survey dengan nilai 
397 dari nilai yang ditetapkan PISA yaitu 500 (Ismail et al., 2018; Lastiningsih et al., 2017). Pada laporan TIMSS tahun 2015, siswa Indonesia berada pada posisi 45 dari 50 negara dengan rata-rata skor 386 (Kartianom \& Retnawati, 2018; Lastiningsih et al., 2017; Mullis et al., 2015). Ini berarti kemampuan pemecahan masalah siswa Indonesia masih rendah dibandingkan Negara lain.

Dalam pendidikan matematika, pemecahan masalah juga menjadi hal yang penting untuk ditanamkan pada diri siswa. Dengan pemecahan masalah matematika, siswa tidak akan kehilangan makna dalam mempelajari matematika karena suatu konsep atau prinsip akan bermakna jika konsep tersebut dapat diaplikasikan dalam pemecahan masalah (Widodo, 2013). Maka dari itu dibutuhkan sebuah inovasi baru dalam pembelajaran untuk mengatasi masalah tersebut, salah satu yang dapat memecahkan masalah yaitu perancangan sebuah media pembelajaran yang dapat membantu siswa. Adanya media dapat mendukung proses pembelajaran, mempermudah siswa dalam memahami materi pembelajaran, serta meningkatkan kualitas mengajar guru yang akan berdampak pada kualitas hasil belajar siswa (El Wida, 2019; Tsany, Septian, \& Komala, 2020).

Pembelajaran sering kali membutuhkan media dalam penyampaiannya, sebagai sarana untuk mempermudah pembelajaran itu sendiri (Yulyantari, 2014; Rizkiani \& Septian, 2019). Menurut teori Bruner dalam proses pembelajaran anak seharusnya diberi kesempatan menggunakan benda atau media pembelajaran untuk digunakan oleh siswa dalam memahami konsep matematika (Arsyad, 2013). Dari pendapat diatas dapat disimpulkan bahwa dalam proses pembelajaran matematika yang dianggap sulit oleh siswa, diperlukan sebuah media pembelajaran yang dapat membantu siswa dalam proses belajar agar pembelajaran menjadi lebih menarik bagi siswa. Hasil penelitian sebelumnya menunjukkan bahwa penggunaan media pada pembelajaran matematika dapat meningkatkan kemampuan memecahkan masalah (Mustafia \& Widodo, 2018; Widodo \& Ikhwanudin, 2018), hal ini menunjukkan bahwa secara umum media pembelajran pop up diduga dapat meningkatkan kemampuan siswa dalam memecahkan masalah matematika.

Pop-up book merupakan sebuah buku yang memiliki bagian yang dapat bergerak atau memiliki unsur 3 dimensi (Widya dkk, 2020). Kegiatan pembelajaran berpusat pada peserta didik, mengembangkan kreativitas, daya nalar, kontekstual, menantang, menyenangkan, menyediakan pengalaman belajar dan belajar dengan berbuat (learning by doing) (Murtianto \& Harun, 2014). Buku pop-up dianggap mempunyai daya tarik tersendiri bagi remaja yaitu dengan menyajikan visualisasi dengan bentuk-bentuk yang dibuat dengan melipat dan sebagainya (Khoirotun dkk, 2014). Siswa pada dasarnya 
terbiasa belajar matematika dengan membaca buku yang terkonsep, maka dengan adanya media pembelajaran Pop Up Book, diharapkan mampu mengatasi masalah matematis siswa dalam proses belajar matematika.

Aritmatika sosial adalah bagian dari ilmu matematika yang membahas tentang perhitungan keuangan dalam perdagangan dan kehidupan sehari-hari beserta aspek sosialnya (Widyaningrum, 2015). Diketahui bahwa materi aritmatika sosial memiliki banyak masalah di kehidupan nyata. Pada kenyataannya di lapangan menunjukkan bahwa tidak sedikit siswa yang kurang memahami materi tersebut (Maslin, 2015). Berkaitan dengan masalah tersebut, diperlukan suatu inovasi pada pembelajaran matematika khususnya materi aritmatika sosial yaitu dengan memanfaatkan media pembelajaran matematika yang dapat meningkatkan kemampuan memecahkan masalah matematis siswa. Maka dari pemaparan diatas peneliti tertarik mengembangkan media pembelajaran berbentuk pop up book untuk pencapaian kemampuan memecahkan masalah matematis pada materi aritmatika sosial.

Pembelajaran matematika materi aritmatika sosial dengan menggunakan media pembelajaran pop up book akan membuat siswa antusias untuk mengikuti pembelajaran di kelas (Nisrina dkk, 2020). Hal ini dapat menjadikan siswa dengan mudah memahami materi dan memecahkan masalah yang berkaitan dengan materi tersebut. Sehingga, media pembelajaran pop up book materi aritmatika sosial dapat dengan efektif mencapai tujuan pembelajaran (Diksa, 2018). Dari penjelasan diatas dapat disimpulkan bahwa, Perancangan Media Pembelajaran Berbentuk Pop Up Book Untuk Pencapaian Kemampuan Mememcahkan Masalah Matematis Pada Materi Aritmatika Sosial, akan sangat membantu siswa maupun guru dalam proses pembelajaran. Dengan adanya media pembelajaran, dapat mempermudah pemahaman siswa dalam upaya memecahkan masalah matematis.

\section{METODE PENELITIAN}

Penelitian ini merupakan penelitian dan pengembangan (Research and development) dengan tujuan merancangan media pembelajaran berbentuk Pop-up Book untuk pencapaian memecahkah masalah matematis pada materi aritmatika sosial. metode penelitian dan pengembangan adalah metode yang digunakan untuk menghasilkan produk tertentu dan menguji kelayakan produk (Sugiyono, 2011). Sedangkan Borg \& Gall (1983) menyatakan bahwa, "Research and Develompment $(R \& D)$ is a process used to develop and validate educational products". Artinya penelitian dan pengembangan merupakan proses yang digunakan untuk mengembangkan dan memvalidasi produk pendidikan. Berdasarkan 
pendapat diatas, maka penelitian pengembangan adalah kegiatan penelitian yang untuk menciptakan, menghasilkan atau mengembangkan suatu produk yang kemudian divalidasi oleh para ahli untuk mendapatkan penilaian/validasi apakah media layak digunakan atau tidak.

Prosedur pengembangan yang digunakan dalam penelitian ini yaitu prosedur penelitian dan pengembangan (Research and Development) model pengembangan 4D (Four-D) yang dikembangkan oleh Thiagarajan dkk (1974) yang terdiri dari empat tahapan yaitu define (pendefinisian), design (perancangan), develop (pengembangan), dan disseminate (penyebaran). Namun, karena keterbatasan waktu dan kondisi pandemi Covid19 di Indonesia, maka penelitian ini hanya dilakukan sampai pada tahapan develop (pengembangan) yaitu sebatas validasi ahli.

Teknik pengumpulan data yang dilakukan pada tahap define adalah dokumentasi dan tahap develop adalah lembar validasi. Sedangkan instrument yang digunakan dalam penelitian adalah instrument lembar validasi guna mengukur kevalidan media Рор-ир book. Lembar validasi ditunjukan kepada ahli untuk memberikan penilaian terhadap aspekaspek untuk menunjang kevalidan media pembelajaran yaitu pop-up book.

Teknik analisis data dimaksudkan untuk mengumpulkan semua item-item dan dianalisis untuk melihat hasil dari sebuah produk pengembangan. Analisis data instrumen validasi untuk melihat validitas media pembelajaran yang dikembangkan berdasarkan skala likert. Penskoran pada analisis data instrumen validasi dapat dilihat pada Tabel 1.

Tabel.1 Kriteria skor

\begin{tabular}{lll}
\hline No & Kriteria & Skor \\
\hline 1 & Sangat baik & 5 \\
\hline 2 & Baik & 4 \\
\hline 3 & Cukup baik & 3 \\
\hline 4 & Kurang baik & 2 \\
\hline 5 & Sangat baik & 1 \\
\hline
\end{tabular}

Analisis data yang digunakan dalam penelitian penelitian pengembangan ini menggunakan teknik analisis data tingkat kevalidan produk. Analisis data kuantitatif (lembar validasi) dalam pengembangan ini menggunakan rumus

$$
P=\frac{\Sigma x}{\Sigma x i} \times 100 \%
$$

Keterangan: 


\section{$P=$ Persentase yang dicari}

$\Sigma x=$ Jumlah skor yang didapat

$\Sigma x i=$ Jumah Skor Maksima

Analisis data dari hasil validasi menggunakan konversi skala tingkat pencapaian, karena dalam penilaian diperlukan standar pencapaian (skor) dan disesuaikan dengan kategori yang telah ditetapkan. Pedoman penilaian skor menurut Sukardi (2009) adalah sebagai berikut:

Tabel 2. Kriteria Angket Penilaian Validator

\begin{tabular}{ll}
\hline Skala Nilai (\%) & Tingkat Validitas \\
\hline $85,00 \leq \mathrm{x}<100$ & Sangat valid, tidak perlu revisi \\
\hline $70,00 \leq \mathrm{x}<85,00$ & Valid, dapat digunakan tetapi perlu revisi kecil \\
\hline $50,00 \leq \mathrm{x}<70,00$ & Kurang valid, dapat digunakan tetapi revisi besar \\
\hline $00,00 \leq \mathrm{x}<50,00$ & Tidak valid, tidak boleh dipergunakan
\end{tabular}

\section{HASIL DAN PEMBAHASAN}

Tahap define (pendefinisian) adalah tahapan awal yang dilakukan pada penelitian ini. Tahapan ini bertujuan untuk menetapkan dan mengidentifikasi syarat-syarat pembelajaran sebelum rancangan media itu sendiri. Dimana tahap ini memiliki beberapa tahapan yaitu: Analisis Awa-akhir. Analisis ini bertujuan untuk mengidentifikasi masalah yang sering dihadapi oleh guru dalam proses pembelajaran matematika. Kedua, Analisis peserta didik bertujuan untuk mengetahui tentang karakteristik siswa yang sesuai dengan rancangan perangkat pembelajaran yang akan dikembangkan (Syafri, 2018). Ketiga, Analisis materi langkah yang dilakukan ialah mengidentifikasi, merinci, dan menyusun secara sistematis materi-materi utama yang akan dipelajari peserta didik. Materi pelajaran dalam penelitian ini adalah Aritmatika sosial. Empat, Tujuan pembelajaran dilakukan untuk mengkonversi tujuan analisis materi menjadi kompetensi dasar yang dinyatakan dengan tingkah laku. Penyusunan tujuan pembelajaran ini didasarkan pada kompetensi dasar dan indikator yang tercantum dalam kurikulum 2013.

Tahap design (perancangan) adalah tahapan yang bertujuan untuk mengghasilkan rancangan sebuah media yang dikembangkan.

Langkah-langkahnya adalah sebagai berikut:

a. Pemilihan Media 
Pemilihan media disesuaikan dengan hasil dari analisis materi yang telah dilakukan sesuai dengan karakteristik peserta didik. Media yang digunakan pada pembelajaran ini yaitu media Pop Up Book yang berperan sebagai media materi inti. Menurut El Wida (2019) media Pop-Up Book bermanfaat dalam proses pembelajaran matematika yakni membantu guru dalam menyampaikan materi kepada siswa. Selain itu, penggunaan Pop Up Book dapat memudahkan siswa dalam belajar matematika.

Buku pop-up dianggap mempunyai daya tarik tersendiri bagi remaja yaitu dengan menyajikan visualisasi dengan bentuk-bentuk yang dibuat dengan melipat dan sebagainya. Siswa pada dasarnya terbiasa belajar matematika dengan membaca buku yang sudah terkonsep, maka dengan adanya media pembelajaran Pop Up Book, diharapkan mampu mengatasi masalah matematis siswa dalam proses belajar matematika dan juga Pop Up Book diharapkan menjadi media pembelajaran yang mampu memberikan sebuah pembalajaran yang menyenangkan bagi siswa agar siswa menikmati proses pembelajaran.

b. Pemilihan Format

Pemilihan format yang dimaksud adalah format yang akan digunakan pada media yang akan dirancang dan dikembangkan. Hal ini dilakukan agar format yang digunakan sesuai dengan materi pembelajaran. Pemilihan format pada media pembelajaran yaitu mendesain isi pembelajaran, mengorganisasikan dan merancang isi media pop-up book.

c. Rancangan Awal

Hasil perancangan awal pada fase ini meliputi rancangan media yang digunakan untuk memperoleh data yang dibutuhkan dalam proses pengembangan. Perancangan media pembelajaran mengacu pada hasil analisis yang telah dilakukan pada tahap pendefinisian. Fase ini akan menghasilkan prototype awal media yang akan dikembangkan pada tahap pengembangan. Adapun hasil rancangan media pembelajaran ini yaitu didasarkan pada kondisi siswa yang lebih menyukai belajar menggunakan media pembelajaran yang baru.

1. Tahap I Rancangan awal

Sebelum menyusun buku, peneliti terelebih dahulu membuat draft atau rancangan konsep yang akan dibuat untuk menentukan isi desain pop up book yang akan digunakan.

2. Tahap II Rancangan awal 
Selanjutnya membuat desain pop up book yang akan digunakan.

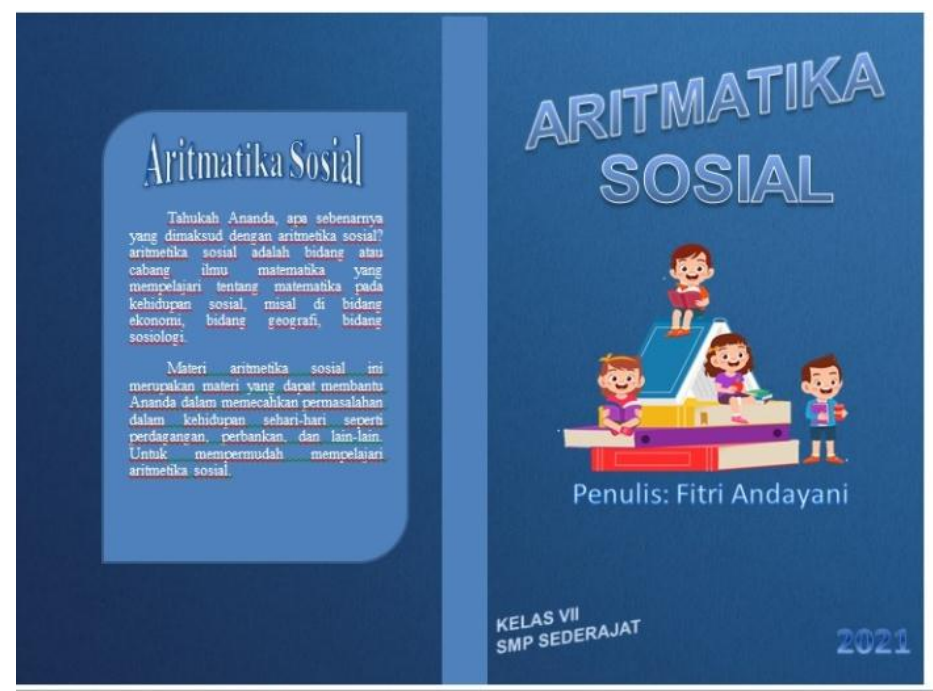

Gambar 1. Desain Awal Sampul

3. Tahap III Rancangan Awal

Setelah desain pop up book selesai, dilanjutkan dengan merancang pop up book sesuai dengan desain awal.

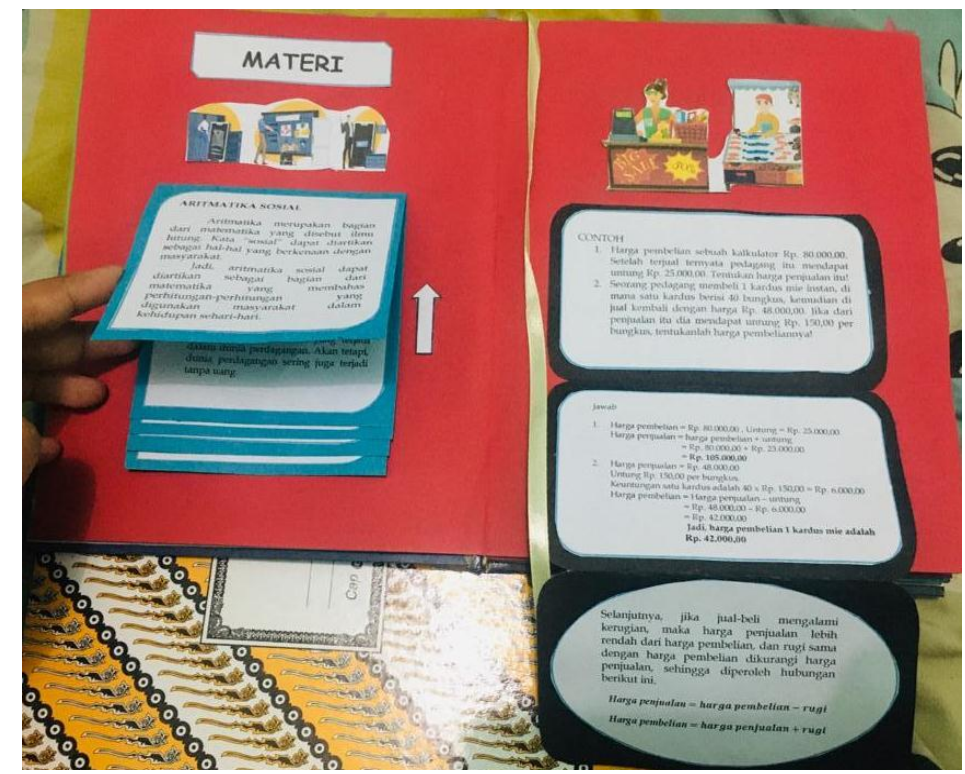

Gambar 2. Desain isi buku Pop up 


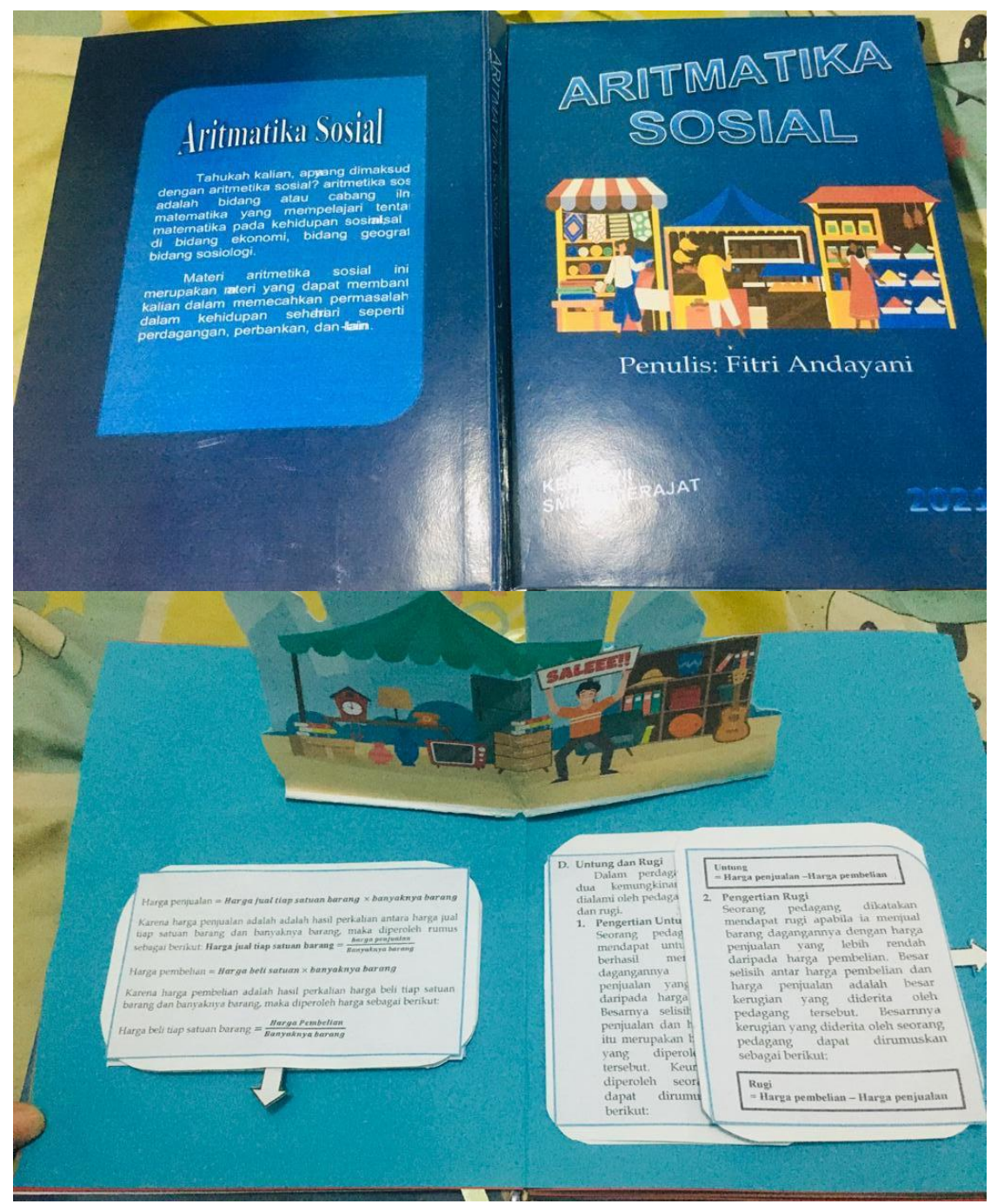

Gambar 3. Desain Prototype

Tahap Develop (pengembangan) tahapan pengembangan terdiri atas penilaian validator ahli. Produk yang telah divalidasi melalui tahap revisi. Validasi ini bertujuan untuk mengetahui kelayakan dari media pembelajaran Pop Up Book yang akan digunakan oleh siswa. Hasil dari validasi ahli media berupa data kuantitatif dan kualitatif. Penilaian kualitatif atau respon dari validator ahli pada media pop up book ialah perlu penambahan ilustrasi dan mengkontraskan warna agar siswa lebih merasa tertarik pada buku Pop-up tersebut. Menurut validator ahli pop-up ini layak digunakan karena media pembelajarn masih sedikit digunakan disekolah karena guru masih banyak menggunakan buku yang biasa. Media pop-up book bukan media yang baru tetapi jarang ada yang memakainya maka dari itu sangat layak diuji cobakan kepada siswa, selaras dengan pendapat El Wida dkk (2019) Tujuan media dalam pembelajaran adalah membantu peserta didik lebih cepat mengetahui, memahami dan upaya terampil dalam mempelajari sebuah materi yang dipelajari. Selain itu juga untuk menciptakan suasana pembelajaran yang menarik, aktif, efektif dan efisien. 
Selain penilaian kualitatif dan penilaian validator ahli, Berdasarkan perhitungan kuantitatif media pembeljaran Pop-up Book hasil validasi dari validator ahi media diperoleh persentase $80,57 \%$, hasil validasi dari validator ahi materi diperoleh persentase $84,286 \%$ dan hasil validasi dari validator ahi bahasa diperoleh persentase $83,88 \%$. Hasil tersebut didistribusikan ke dalam tabel 2 sehingga diperoleh tingkat validitas yaitu valid dapat digunakan tetapi perlu revisi kecil, maka media Pop-up Book dikategorikan valid digunakan pada pembelajaran materi aritmatika sosial. Setelah produk direvisi berdasarkan masukan dan saran dari validator ahli, selanjutnya produk diuji cobakan secara terbatas. Namun pada penelitian ini tahapan develop hanya dilakukan sampai pada validasi para ahli dan revisi sesuai masukan dan saran para validator ahli, dikarenakan situasi pendidikan yang belum stabil karena virus Covid-19 yang mana siswa masih menjalankan pembelajaran secara daring serta keterbatasan waktu dalam penelitian.

Tahap Disseminate (penyebarluasan) Pada penelitian ini belum sampai pada tahap Disseminate (Penyebarluasan). Ini dikarenakan peneliti menemukan kendala dalam proses penelitian yaitu karena virus Covid-19 yang menyebabkan dihentikannya proses belajar mengajar secara tatap muka serta keterbatasan waktu penelitian. Dengan demikian, penelitian ini hanya sampai pada tahap develop

Media pembelajaran adalah alat yang dapat membantu proses belajar mengajar dan berfungsi untuk memperjelas makna pesan yang disampaikan, sehingga dapat mencapai tujuan pembelajaran dengan lebih baik dan sempurna (Dula, 2017). Seperti diketahui bahwa media pembelajaran adalah sarana untuk meningkatkan kegiatan proses belajar mengajar. Dalam proses pembelajaran, media memiliki fungsi sebagai pembawa informasi dari sumber (guru) menuju penerima (siswa) (Aprilia \& Supriadi, 2019).

Dalam proses pembelajaran matematika yang abstrak, siswa masih memerlukan alat bantu dalam proses pembelajaran yang berupa media pembelajaran. Oleh karena itu peneliti ingin mengembangkan media berupa sebuah buku Pop-up yang diharap mampu membantu proses belajar mengajar matematika. Buku Pop-up merupakan media yang dirancang oleh peneliti agar membantu siswa dalam memahami materi aritmatika sosial agar mampu memecahkan masalah matematis dalam proses pembelajaran, serta media ini juga diharapkan dapat membantu guru dalam menyampaikan materi kepada siswa sehingga tujuan pembelajaran tercapai. Disamping itu dengan desainnya yang menarik dan sesuai karakteristik siswa media Pop-Up Book ini dapat meningkatkan dan mengarahkan perhatian anak pada saat pembelajaran berlangsung (El Wida, 2019). 
Penelitian pengembangan ini menghasilkan produk berupa media pembelajaran Pop-up Book, serta untuk mengetahui kelayakan terhadapat media Pop-up Book proses desain perancangan produk Pop-up Book memiliki beberapa tahap yang diawali dengan mengumpulkan informasi tentang potensi dan masalah kemudian dilakukan studi tentang potensi dan masalah tersebut. Setelah itu dilanjutkan ke tahap perancangan produk berupa pemilihan media yang dikembangkan serta materi media yang dipilih untuk dikembangkan adalah media pop-up book untuk pencapaian kemampuan memecahkan masalah matematis pada materi aritmatika sosial. Pemilihan media Pop-up Book didasarkan pada pendapat siswa yang lebih menyukai Proses Belajar Mengajar (PBM) menggunakan media.

Kemudian dilanjutkan dengan tahap mendesain produk. Pada tahap pengembangan ini yang paling banyak menghabiskan waktu, karena sangat detail dan perlu ketelitian dalam menyusun Pop-up Book dan harus mengumpulkan materi terlebih dahulu dari berbagai sumber serta membuat desain produk awal hingga akhir sampai desain Pop-up Book yang dikembangkan benar-benar siap untuk di validasi oleh validator ahli. Produk Pop-up Book merupakan jenis media pembelajaran. Media pembelajaran adalah segala sesuatu yang dapat digunakan untuk menyalurkan pesan (bahan pembelajaran), sehingga dapat merangsang perhatian, minat, pikiran, dan perasaan pembelajar dalam kegiatan belajar untuk mencapai tujuan pembelajaran tertentu (Sumiharsono \& Hasanah 2017).

Setelah produk tersebut didesain tahap selanjutnya yaitu tahap validasi desain produk, revisi produk dan uji coba produk, proses uji coba tersebut sampai didapatkan data yang akurat sehingga Pop-up Book tersebut layak digunakan namun disini peneliti hanya sampai tahap develop bagian revisi, yang mana tahapan uji coba terbatas dan disseminate tidak dilakukan karena terkendala akibat Covid-19 yang melanda Indonesia yang mengakibatkan sekolah harus secara online serta keterbatasan waktu penelitian.

Setelah produk tersebut didesain tahap selanjutnya yaitu tahap validasi desain produk, revisi produk dan uji coba produk, proses uji coba tersebut sampai didapatkan data yang akurat sehingga Pop-up Book tersebut layak digunakan namun disini peneliti hanya sampai tahap develop bagian revisi, yang mana tahapan uji coba terbatas dan disseminate tidak dilakukan karena terkendala akibat covid-19 yang melanda Indonesia yang mengakibatkan sekolah harus secara online serta keterbatasan waktu dalam penelitian.

Penggunaan media pembelajaran bukan merupakan fungsi tambahan, tetapi memiliki fungsi tersendiri sebagai sarana bantu untuk mewujudkan situasi pembelajaran yang lebih efektif. Media pembelajaran bukan berfungsi sebagai alat hiburan, dengan demikian tidak diperkenankan untuk menggunakannya hanya sekedar untuk permainan 
atau memancing perhatian siswa semata. Media pembelajaran berfungsi untuk meningkatkan kualitas proses belajar-mengajar. Menurut Giyanti (2018) Media pembelajaran adalah komponen sumber belajar atau wahana fisik yang mengandung materi instruksional yang dapat merangsang peserta didik untuk belajar. Maka dari itu media pembelajaran diharapkan mampu meningkat pencapaian kemapuan memecahkan masalah matematis.

\section{KESIMPULAN}

Berdasarkan hasil dan pembahasan yang telah diuraikan diatas, dapat disimpulkan bahwa perancangan media pembelajaran berbentuk pop-up book untuk pencapaian kemampuan memecahkan masalah matematis dikatakan valid valid tetapi diperlukan perbaikan kecil. Perbaikan kecil yang disarankan oleh validator secara umum telah dilakukan, sehingga produk media pembelajaran berbentuk pop-up book pada materi aritmatika social dapat diujicobakan untuk melihat apakah ada efek terhadap kemampuan memecahkan masalah.

\section{REFERENSI}

Aprilia, E., \& Supriadi, N. (2019). Pengembangan media pembelajaran matematika berupa kotak pop-up untuk anak autisme. Desimal: Jurnal Matematika, 2(3), 241-247.

Arsyad, A. (2013). Media Pembelajaran. Jakarta: Rajawali Pers.

Bernard, M., Nurmala, N., Mariam, S., \& Rustyani, N. (2018). Analisis kemampuan pemecahan masalah matematis siswa SMP kelas IX pada materi bangun datar. SJME (Supremum Journal of Mathematics Education), 2(2), 77-83.

Borg, W. R., \& Gall, M. D. (1983). Educational Research an Introduction. $4^{\text {th }}$ ed. New York: NY: Longman, Inc.

Diksa, T. N. (2018). Media pembelajaran pop up book materi aritmatika sosial kelas VII SMP. Universitas Muhammadiyah Malang.

Dula, S. N. G. (2017). Pengembangan media pop up book pada materi bentuk permukaan bumi untuk siswa kelas III SDN Mangunsari Semarang. Universitas Negeri Semarang.

El Wida, I. R. M. A., Muhsinin, U., \& Mukminin, A. (2019). Pengembangan media matematika berupa pop-up book kelas IV madrasah ibtidaiyah nurul ittihad Kota Jambi. UIN Sulthan Thaha Saifuddin Jambi).

Fuadah, S., Eliasar, V., \& Fauzi, A. (2019). Desain bahan ajar menggunakan pop-up book pada materi spldv terhadap kemampuan pemecahan masalah matematis. In Prosiding Seminar Nasional Pendidikan Matematika (SNPM) (Vol. 1, No. 1, pp. 561-572).

Giyanti. (2018). Pengembangan media pembelajaran pop up book untuk peserta didik tunarungu SMP-LB pada materi gerak dan daya. Universitas Islam Negeri Raden Intan Lampung.

Ismail, H. H., Duskri, M., Zubainur, C. M., \& Munzir, S. (2018). Analysis of student ability in solving PISA-like math problems : a case study in SMPN 8 Banda Aceh, 
Indonesia. International Journal of Scientific Research and Management (IJSRM), 06(12), 139-143.

Kartianom, K., \& Retnawati, H. (2018). Why are their mathematical learning achievements different? re-analysis timss 2015 data in indonesia, japan and turkey. International Journal on New Trends in Education and Their Implications, 9(2), 33-46.

Khoirotun, A., Fianto, A. Y. A., \& Riqqoh, A. K. (2014). Perancangan buku pop-up museum Sangiran sebagai media pembelajaran tentang peninggalan sejarah. Universitas Dinamika.

Lastiningsih, N., Mutohir, T. C., Riyanto, Y., \& Siswono, T. Y. E. (2017). Management of the School Literacy Movement (SLM) Programme in Indonesian Junior Secondary Schools. World Transactions on Engineering and Technology Education, 15(4), 384-389.

Maslin, F. D. (2015). Pengembangan web quest berbasis problem based learning pada pembelajaran matematika materi aritmatika sosial kelas VII SMPN 3 Malang. Universitas Muhammadiyah Malang.

Mullis, I. V. S., Martin, M. O., Foy, P., \& Hooper, M. (2015). TIMSS 2015 International Results in Mathematics. New York: TIMSS \& PIRLS.

Murtianto, Y. H., \& Harun, L. (2014). Pengembangan strategi pembelajaran matematika smp berbasis pendekatan metakognitif ditinjau dari regulasi diri siswa. AKSIOMA: Jurnal Matematika dan Pendidikan Matematika, 5(2/septembe).

Mustafia, I. D., \& Widodo, S. A. (2018). Problem solving skill: Effectiveness on think pair share with comic. International Journal on Teaching and Learning Mathematics, 1(2), 76-83.

Nisrina, R., Palupi, W., \& Pudyaningtyas, A. R. (2020). Peningkatan kemampuan mengenal konsep bilangan melalui penggunaan media pop-up picture book anak usia 4-5 tahun. Kumara Cendekia, 8(3), 342-355.

Norhayati, N., Hasanuddin, H., \& Hartono, H. (2018). Pengembangan media pembelajaran berbasis contextual teaching and learning untuk memfasilitasi kemampuan pemecahan masalah matematis siswa madrasah tsanawiyah. JURING (Journal for Research in Mathematics Learning), 1(1), 19-32.

Rizkiani, A., \& Septian, A. (2019). Kemampuan metakognitif siswa SMP dalam pembelajaran matematika dengan menggunakan pendekatan realistic mathematics education ( RME ). UNION: Jurnal Pendidikan Matematika, 7(2), 275-284.

Septian, A. (2017). Penerapan Geogebra untuk meningkatkan kemampuan pemecahan masalah matematis mahasiswa Program Studi Pendidikan Matematika Universitas Suryakancana. PRISMA, 6(2). https://doi.org/10.35194/jp.v6i2.212

Soeprapto, S. (2013). An axiological foundation of the indonesian national education system in the perspective of philosophy of education. Cakrawala Pendidikan (2):266-76.

Sugiyono. (2011). Metode penelitian kualitatif, kuantitatif dan $R \& D$. Bandung: Alfabeta.

Sukardi. (2009). Evaluasi Pendidikan, Prinsip \& Operasionalnya. Yogyakarta: Bumi Aksara.

Sumiharsono, R., \& Hasanah, H. (2017). Media pembelajaran: buku bacaan wajib dosen, guru dan calon pendidik. Pustaka Abadi.

Suryana, S. (2020). Permasalahan mutu pendidikan dalam perspektif pembangunan pendidikan. Edukasi, 14(1).

Syafri, F. S. (2019). Pengembangan modul pembelajaran aljabar elementer di Program Studi Tadris Matematika IAIN Bengkulu. CV. Zigie Utama. 
Thiagarajan, S., D. S. Semmel, and M. I. Semmel. 1974. Instructional development for training teachers of exceptional children: a sourcebook (issue mc). Center for Innovation in Teaching the Handicappe, Indiana University.

Tsany, U. N., Septian, A., \& Komala, E. (2020). The ability of understanding mathematical concept and self-regulated learning using macromedia flash professional 8. Journal of Physics: Conference Series, 1657(1), 012074. https://doi.org/10.1088/17426596/1657/1/012074

Widodo, S. A. (2013). Analisis kesalahan dalam pemecahan masalah divergensi tipe membuktikan pada mahasiswa matematika. Jurnal Pendidikan Dan Pengajaran 106-13.

Widodo, S. A., \& Ikhwanudin, T. (2018). Improving mathematical problem solving skills through visual media. In Journal of Physics: Conference Series (Vol. 948, No. 1, p. 012004). IOP Publishing.

Widya, P. N., Ariyanto, L., \& Murtianto, Y. H. (2020). Pengembangan bahan ajar matematika berbasis contextual teaching and learning berbantuan pop up book untuk meningkatkan kemampuan penalaran matematis siswa Kelas VII. Imajiner: Jurnal Matematika dan Pendidikan Matematika, 2(2), 95-101.

Widyaningrum, I. (2015). Desain pembelajaran materi aritmatika sosial dengan model permainan pasar-pasaran. In Prosiding Seminar Nasional Pendidikan Matematika (SNAPTIKA) (Vol. 19, pp. 247-709).

Yulyantari, L. M. (2015). Perancangan media pembelajaran dengan penerapan metode jigsaw. Sisfotenika, 5(2), 95-106. 